\title{
Social Efficiency of Microfinance Institutions in India: A Data Envelopment Analysis
}

\author{
Effulgence \\ Vol. 17, No. 2 (Special Issue) \\ July - December 2019 \\ Rukmini Devi Institute of Advanced Studies \\ E-mail : effulgence@rdias.ac.in, Website : www.rdias.ac.in \\ http://effulgence.rdias.ac.in/user/default.aspx \\ https://dx.doi.org/10.33601/effulgence.rdias/v17/iSpl2/2019/58-76
}

\author{
Dr. Prabhjot Kaur ${ }^{1}$ \\ Dr. Soma Dey²
}

\begin{abstract}
In the third quarter of 2015, RBI granted small finance bank licenses to several Indian Microfinance Institutions (MFIs), acknowledging the importance of MFIs as grass-roots level institutions to achieve the goal of financial inclusion. The social objectives of MFIs have once again come at the forefront, following the turn-around of the sector post-2010 Andhra Pradesh microfinance crisis. This study contributes to that ongoing discussion by evaluating the social efficiency of 49 MFIs in India using Data Envelopment Analysis. Ranking to MFIs has been assigned using super efficiency scores. The study has shown the scope of reaching more number of poor and women without increasing the use of resources. The key is to utilize the resources efficiently. Using slacks, the scope of plugging the wastages of inputs for individual MFI has been worked out in the study and also benchmark MFIs are identified for relatively inefficient MFIs. The assigned ranking to the chosen sample of MFIs and the detection of scope of improvement in the efficiency have implications for both policy-makers and MFIs. They can use the ranking of MFIs on social efficiency front to assess the relative performance as well as gain understanding of areas of improvement by identifying the input and output slacks.
\end{abstract}

Keywords: Microfinance Institutions, Social Efficiency, Data Envelopment Analysis, Super efficiency. JEL G21, G23, O16

\section{INTRODUCTION}

$W^{2}$ orldwide 2 billion people have no access to formal banking (Demirguc-Kunt et al., 2015). Microfinance Institutions (MFIs) had been looked upon as an important link to connect the marginalized people to formal financial institutions and more broadly to the financial system. The potential of MFIs has been recognized by the United Nations in achieving the Millennium Development

1. Assistant Professor, Indraprastha College for Women, University of Delhi, New Delhi, India, prabhjot.fms@gmail.com 2. Assistant Professor, Faculty of Management Studies, University of Delhi, New Delhi, India, soma.dey@fms.edu 
Goals. The United Nations celebrated the year 2005 as the 'International Year of Microfinance'. Microfinance institutions not only provide microcredit to the poor but also provide them other financial services including savings, insurance, pension, remittances, etc. However, their role as profit and as nonprofit institutions to serve poor and marginalized has always been an issue of debate. Incidents of over-indebtedness among borrowers and their subsequent mistreatment by the MFI staff members and suicide by borrowers (in Andhra Pradesh during 2010, among others) have given a further push to this debate. Studies like Hulme and Maitrot (2014) have contended that MFIs in South Asia have lost their moral intent and they tend to achieve their financial objectives at the cost of their social objectives. Based on the objectives pursued by microfinance institutions, Conning and Morduch (2011) have characterized MFIs as either for-profit with social mission or nonprofit with financial mission as well as institutions that lie somewhere in between these two types. This study attempts to understand the current scenario of the Indian MFIs in terms of their social efficiency. Providing microfinance services to poor and women are considered as the social objectives of MFIs. Social efficiency of MFIs used in this paper is in the context of measuring their technical efficiency to achieve their social objectives. Thus, social efficiency implies here the ability of MFIs to use minimum inputs to reach maximum number of poor and women.

The Reserve Bank of India (RBI) and government of India are continually directing their efforts to achieve financial inclusion in India. The Rangarajan Committee on Financial Inclusion, 2008 defines financial inclusion as a system that provides "delivery of financial services at an affordable cost to the vast sections of the disadvantaged and lowincome groups". To be financially inclusive, the RBI stipulates a system which has several components, the most important among them being identifying, and delivering financial services to the most economically vulnerable section of the population, especially poor women, when they need it the most.
Access to affordable credit in the absence of physical collateral, which can be used for contingency planning or wealth creation and finally lead to inclusion in the formal banking system, are some of the defining features of the concept of financial inclusion. In the model followed by RBI, the SHGs and MFIs are looked upon as important tools for financial inclusion. Given the importance of the social objectives of MFIs, especially in a country like India where widespread financial inclusion yet remains a distant dream, this paper analyzes the social efficiency of Non Banking Financial Institutions (NBFI)-MFIs in India. There is a lack of studies that have focused on measuring the social efficiency of MFIs in the Indian context.

This study contributes to the existing literature by assigning the strict ranking to MFIs in India and hence identification of socially efficient MFIs for the chosen sample. The study also contributes towards ascertaining the wastage of resources for the individual MFIs and provides a direction of possible reduction in the inputs to realize the social goals more efficiently. Identification of efficient MFIs finds relevance in the present context as efficient MFIs are being recognized as an important tool to achieve the objective of financial inclusion. Recognizing the wastage of resources is crucial as MFIs are expected to achieve the double bottom line. They are expected to reach a large number of poor while being sustainable in their operations. Thus, plugging the wastage of resources can increase efficiency as same number of poor and women could be reached with lesser inputs. Thus addressing inefficient utilization of resources can help in defying the alleged trade-off between financial and social efficiency. Specifically, this study seeks to achieve the following four objectives:

1. To Measure social efficiency of individual NBFIMFIs in India.

2. Provide a strict ranking to NBFI-MFIs based on their super efficiency scores.

3. Identifying optimal resource mix for relatively inefficient MFIs using slacks.

4. Identifying benchmark MFIs to improve the 
efficiency of relatively inefficient MFIs.

Rest of the paper is organized as follows: Section 2 highlights some recent developments in the microfinance industry in India. Section 3 provides the literature review on measuring the efficiency. Section 4 discusses the methodology and model specification. Section 5 measures the social efficiency, provides rankings, and suggests measures to improve the efficiency of inefficient MFIs and section 6 presents conclusion and major policy implications of the study.

\section{MICROFINANCE IN INDIA}

The history of private sector MFIs in India can be traced back to the late sixties and the early seventies with the initiatives of Self Employed Women's Association (SEWA) and Mysore Rehabilitation and Development Agency (MYRADA). Post 1992, the Self-Help-Group (SHG) model for dispensing microcredit got a boost after the involvement of National Bank for Agriculture and Rural Development (NABARD). The 2010 microfinance crisis in Andhra Pradesh (AP crisis) hit the microfinance industry in India very hard (Kaur and Dey, 2013). The crisis left some MFIs with negative net worth. Banks also felt the pinch of the crisis as they account for 80 percent of borrowing by MFIs. Crunch of funds, escalating operating costs and negative perceptions proved fatal for the microfinance sector in India. However, after the year 2011 microfinance sector in India has bounced back. In 2011, gross loan portfolio of MFIs stood at Rs. 30,000 crores, almost half of its size in 2010. It climbed to Rs.70,000 crores in 2015. MFIs now are reaching nearly 37 million borrowers (figure 1). Out of these, approximately 32 million clients (85 percent) are being reached by NBFI-MFIs alone. MFIs have spread their operations in 28 states, 5 Union Territories, and 568 districts. There exist regional disparities in the spread of outreach of MFIs. Figure 2 shows the region-wise outreach of clients by MFIs in India; south and north region has the highest and the lowest outreach respectively
(The Bharat Microfinance Report, 2015). Concerns have been raised over the high rate at which sector is growing as it may create another AP like situation. However, the sector has become much more robust than it was before 2010 .

AP crisis had brought changes in the regulation of MFIs in India. In 2011, RBI created a new category for NBFIs catering to microfinance services as NBFIMFIs. These NBFI-MFIs are required to follow the stipulated guidelines in terms of minimum net worth, qualifying assets, maximum amount and the tenure of loan, average interest to be charged, frequency of repayment installments and mandatory membership of Credit Information Bureau etc. For responsible lending and grievance redressal system for borrowers, the RBI appointed Microfinance Institution Network (MFIN) and Sa-Dhan as two 'Self-Regulatory Organizations' for NBFI-MFIs. Transforming of NGOs into NBFIs, availability of funding partners, innovations and urgency of financial inclusion are several other contributing factors that have helped in the overhauling of the sector (Nair and Tankha, 2014). The RBI has also acknowledged the improvements of the sector and has expanded the scope of MFIs by raising the limits of lending as well as by broadening the consumer base (Nair, 2015). Actions of the RBI with respect to this sector for the last two years show a new urge to broaden the reach of financial inclusion using the MFI network. In June 2015, RBI granted the final approval to Bandhan to operate as a commercial bank, while not considering corporate heavyweights like Reliance ADA group, Aditya Birla group, and Bajaj group. Bandhan was the largest MFI (with a loan portfolio of $\$ 1.6$ billion) and the first microlender to become a bank in India. In September 2015, the RBI granted "in-principle" approval to 10 applicants to set up small finance banks (SFB), out of which 8 were MFIs (Nair, 2015). The list of applicants included 72 entities and the list approved by RBI shows a clear preference towards organizations that have done well in priority sector lending. 
In the light of RBI's actions and the broader national objective of financial inclusion, understanding the achievements of individual MFIs on social parameters becomes essential. This paper attempts to address this issue by analyzing the social performance of 49 NBFI-MFIs operating in India.

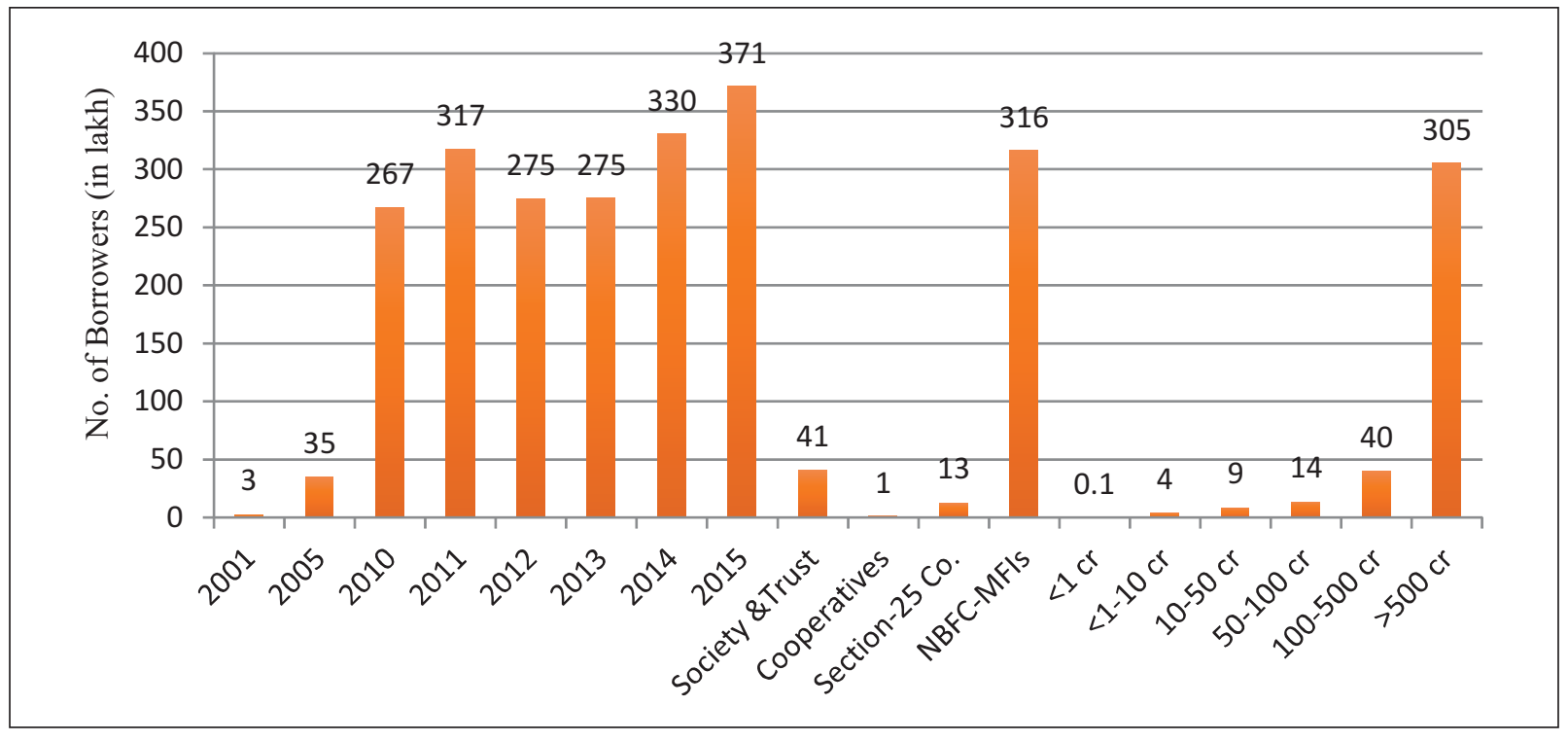

Source: The Bharat Microfinance Report, 2015

Figure 1: Microfinance client outreach and category wise breakup for 2015

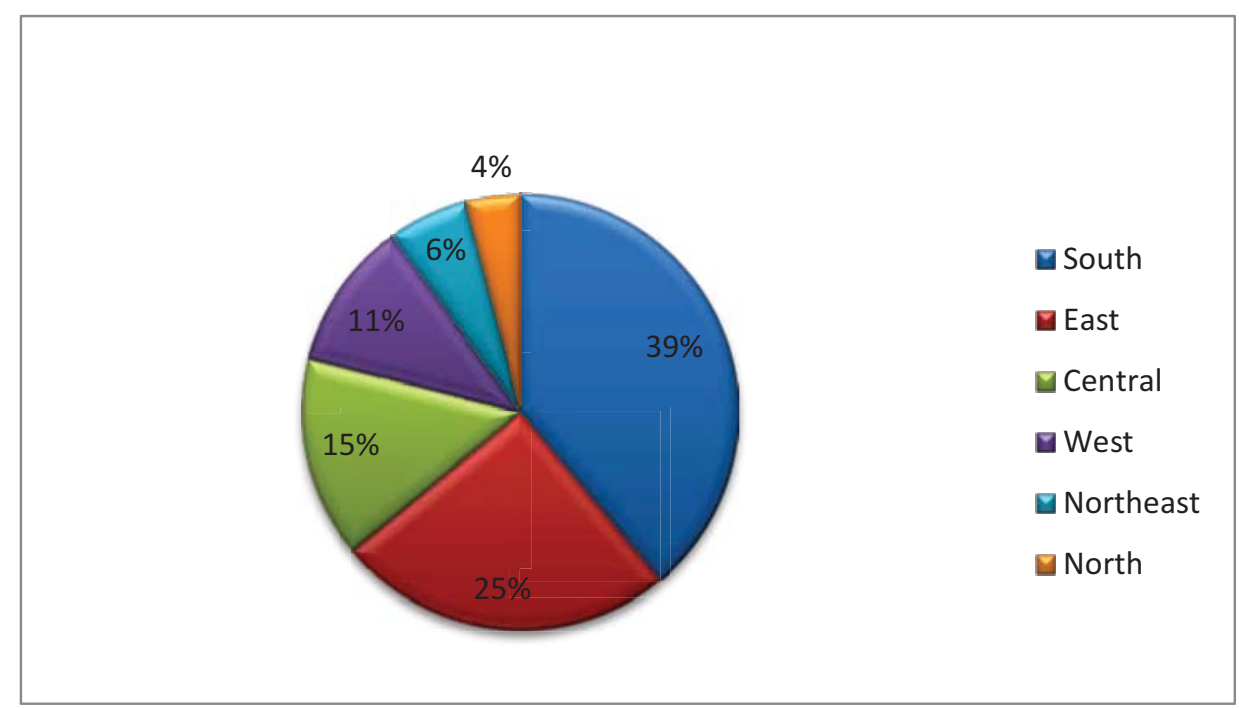

Source: The Bharat Microfinance Report, 2015

Figure 2: Region wise client outreach 


\section{LITERATURE REVIEW}

Focusing on the self-sufficiency and efficiency of MFIs started gaining ground from the failure of Rural Development Institutions in Less Developing Countries in 1960 and 1970 that relied heavily on the subsidized credit. Curtailing the subsidized credit necessitates on the part of MFIs to generate sufficient revenue to meet the high transaction costs involved in lending the poor (Woller et al., 1999). Observers have alleged that to raise revenue, MFIs are shifting their focus from poor to non-poor or relatively better-off clients. Thus, MFIs are sidelining their social objectives. The alleged drift in their mission stirred the debate between those who see a bigger and direct role for the welfare state and those who believe in strengthening the institutions. The welfare school of thought favors serving a large number of poor; source of funding is not a major concern for them. Whereas, considering the fact that donations and subsidies are not reliable sources of funds to fulfill the credit need of the poor persistently, the institutionalist school argues for the self-sufficiency of the operations of the microfinance institutions. To achieve the twin objectives of MFIs it is argued that they should increase the efficiency of their operations (Brand 2000; Farrington 2000).

In India, there exists a huge gender gap in terms of access to formal finance. Global Findex database 2014 reveals that in India only $43 \%$ of female adults have an account with a formal financial institution as compared to $63 \%$ of male adults (Demirguç-Kunt et al, 2015). Illiteracy among women and lack of ownership of assets pose a big hurdle in accessing finance. Microfinance institutions and SHGs are helping women immensely to overcome these hurdles by providing them with access to finance without any collateral. The barrier of illiteracy is overcome, as the process of taking a loan is simple and being taken care of by the field staff itself. However, to serve the social objectives, the efficiency of Indian MFIs in utilizing their resources is an issue that needs to be analyzed.
In the recent past measuring the social efficiency of MFIs have gained ground (Gutierrez-Goiria et al., 2017; Azad et al., 2016; Huq et al., 2017; Wijesiri et al., 2017). In microfinance literature, social efficiency is used in terms of efficiency of MFIs in achieving their social objectives. Social objectives of MFIs are measured by their outreach to the poor. Outreach can be viewed from the perspective of depth and breadth. The breadth of outreach signifies the number of clients reached. Depth takes into consideration the weight or preference society gives to the client in social welfare function. Thus, more the preference MFIs give to poor and women, greater will be the depth of outreach (Schreiner, 2002). The most common proxies used to measure the depth of outreach are the number of women borrowers reached and the average size of loan outstanding per borrower. Thus, social efficiency used in this paper is in the context of how efficiently MFIs are utilizing their resources to achieve social objectives of reaching poor and women. GutierrezNieto et al. (2009) made an important contribution in measuring the social objectives of MFIs. They have constructed a poverty index to measure the social efficiency by integrating both the dimensions of outreach. Their results of Data Envelopment Analysis (DEA) show that, barring one case, all the socially efficient MFIs were financially efficient; however, the reverse was not true. Their study shows that in order to serve the poor for the longer term, MFIs have to be financially sustainable. Some studies have shown targeting women affect efficiency negatively (Hermes et al., 2011; Annim 2012). Lebovics et al. (2016) have estimated financial and social efficiency using DEA. Their study on Vietnamese MFIs show in the presence of support of subsidies MFIs are able to achieve high financial efficiency and social efficiency simultaneously. Several studies have used Stochastic Frontier Analysis (Hassan\& Tufte, 2001; Lamberte and Desrochers, 2002; Paxton, 2007; Servin et al., 2012) and measured efficiency considering aspects like corporate governance, ownership etc. However, some studies (Nghiem et al., 2006; Annim, 2012) have used both Data Envelopment Analysis and 
Stochastic Frontier Analysis to compare the efficiencies. Wijesiri et al. (2017) study how size and age of MFIs are related with their financial and social objectives. They establish that larger MFIs perform their financial and social objectives in a better way. However, for age, their findings represent a mixed result. Gutierrez-Goiria et al. (2017) assert that social and financial objectives of MFIs can go hand in hand. They find legal status and target market as important determinants of social and economic efficiency. For the variables age and scale, the results of univariate analysis are not in congruence with the results of regression analysis. The univariate analysis has found an inverse relationship between scale and efficiency; whereas, regression results have established a positive relationship between the two variables. The next section discusses the model specification and methodology of data analysis used in this paper.

\section{Methodology and Model Specification to Measure Social Efficiency of Microfinance Institutions}

In the present study, Data Envelopment Analysis has been used to analyze the social efficiency of MFIs in India. DEA uses linear programming to measure relative efficiency of homogeneous set of DecisionMaking Units (DMUs). It has capability to incorporate multiple inputs and outputs. In DEA, each unit of analysis is treated as DMU. Thus, in the present study, each MFI will be treated as a DMU. By using linear programming, it fits a piecewise linear frontier. Input oriented DEA model seeks to maintain the same level of outputs while reducing the usage of inputs proportionally. Similarly, the output-oriented model attempts to increase the outputs proportionally while maintaining the same level of inputs. We have measured social efficiency using input oriented model developed by Charnes et al. (1978). Further, we have calculated the super efficiency scores of MFIs using radial - CRS super efficiency model suggested by Andersen and Petersen (1993) as elaborated below.

For a set of $n$ DMUs, denoted by DMUj $(j=1,2, \ldots n)$, using inputs $\mathrm{X} \in \mathrm{R}^{\mathrm{m}}{ }_{+}$to produce outputs $\mathrm{Y} \in \mathrm{R}^{\mathrm{s}}$. For $D M U j$, using $x_{i j}$ quantity of $i^{\text {th }}$ input and $y_{\mathrm{rj}}$ quantity of $\mathrm{r}^{\text {th }}$ output, the input-oriented Social Efficiency (SE) denoted by $\theta$ under Constant Return to Scale (CRS) is calculated as follows

$$
\min _{\theta_{k}, \lambda, s_{i}^{-}, s_{r}^{+}} \mathbf{S E}^{\mathbf{k}}=\tau_{k}-\eta\left(\sum_{i=1}^{m} \mathbf{s}_{\mathbf{i}}^{-}+\sum_{r=1}^{s} \mathbf{s}_{\mathbf{r}}^{+}\right)
$$

Subject to:

$$
\begin{aligned}
& \sum_{j=1}^{n} \lambda_{\mathrm{j}} \mathrm{x}_{\mathrm{ij}}+\mathbf{s}_{\mathrm{i}}^{-}=\theta_{\mathrm{k}} \mathrm{x}_{\mathrm{ik}}, \quad \mathrm{i}=1,2, \ldots, \mathrm{m} \\
& \sum_{j=1}^{n} \lambda_{\mathrm{j}} \mathrm{y}_{\mathrm{rj}}-\mathbf{s}_{\mathrm{r}}{ }^{+}=\mathrm{y}_{\mathrm{rk}}, \quad \mathrm{r}=1,2, \ldots, \mathrm{s} \\
& \mathbf{s}_{\mathrm{i}}^{-}, \mathbf{s}_{\mathbf{r}}^{+} \geq 0 \\
& \lambda_{\mathrm{j}} \geq 0, \quad j=1,2, \ldots, n
\end{aligned}
$$

The model represented above is solved in two stages. In stage one, maximum reduction of inputs for $\mathrm{DMU}_{\mathrm{k}}$ is sought. In stage two, optimization of input and output slacks is done to facilitate the movement on the efficient frontier. $\varepsilon$ is a non-Archimedean infinitesimal. $\mathrm{S}_{1}^{-}$and $\mathrm{S}_{\mathrm{r}}^{+}$are non-negative input and output slack respectively. The restriction $\mathrm{V}$ limits the weight assigned to be non-negative. This model gives the efficiency score for $\mathrm{DMU}_{\mathrm{k}^{\prime}}$ in order to obtain efficiency score of each DMU in the sample we need to run the model for each of the $n$ DMUs involved in the analysis.

The radial - CRS super efficiency model suggested by Andersen and Petersen (1993) is given by

$$
\min _{\theta_{k}, \lambda, s_{i}^{-}, s_{r}^{+}} S E^{k, s u p e r}=\tau_{k}^{\text {super }}-\eta\left(\sum_{i=1}^{m} s_{i}^{-}+\sum_{r=1}^{s} s_{r}^{+}\right)
$$

Subject to:

$$
\begin{array}{ll}
\sum_{\substack{j=1 \\
j \neq k}}^{n} \lambda_{j} x_{i j}+s_{i}^{-}=\theta_{k}{ }^{\text {super }} x_{i k}, & i=1,2, \ldots, m \\
\sum_{\substack{j=1 \\
j \neq k}}^{n} \lambda_{j} y_{r j}-s_{r}^{+}=y_{r k}, & r=1,2, \ldots, s
\end{array}
$$




$$
\begin{aligned}
& s_{i}{ }^{-}, s_{r}{ }^{+} \geq 0 \\
& \lambda_{j}(j \neq k) \geq 0, \quad j=1,2, \ldots, n
\end{aligned}
$$

\section{Checking the robustness of the efficiencies}

DEA analysis will give erroneous result if data is contaminated by outliers. To detect the presence of outliers measure of super efficiency has been employed. The method of calculation of input oriented super efficiency is illustrated in figure 3. Initially, we have efficiency frontier constructed by the line segments joining three efficient DMUs A, B, and $C$. For the calculation of the super efficiency of DMU B, it cannot be the part of the reference set. Thus, DMU B is removed from the reference set. A new frontier is formed by joining DMU A and DMU
C. Super efficiency of DMU B becomes $\mathrm{OB}^{\prime} / \mathrm{OB}>1$. Thus super efficiency score will always be greater than one. However, for inefficient units score remains the same. Super efficiency overcomes the limitation of Charnes, Cooper, and Rhodes (CCR) model that assigns equal value to efficient units i.e. 1, and which further makes the differentiation among efficient units difficult. Super efficiency score suggested by Anderson and Peterson (1993) has been used in this study. Super efficiency score facilitates two purposes; one it helps in the ranking of the DMUs; secondly, scores can be used for the further analysis to check the presence of outliers. A super efficiency score greater than or equal to 2 shows the presence of a potential outlier (Avkiran, 2006). No outlier is detected in our study as none of the super efficiency scores lie above the threshold value.

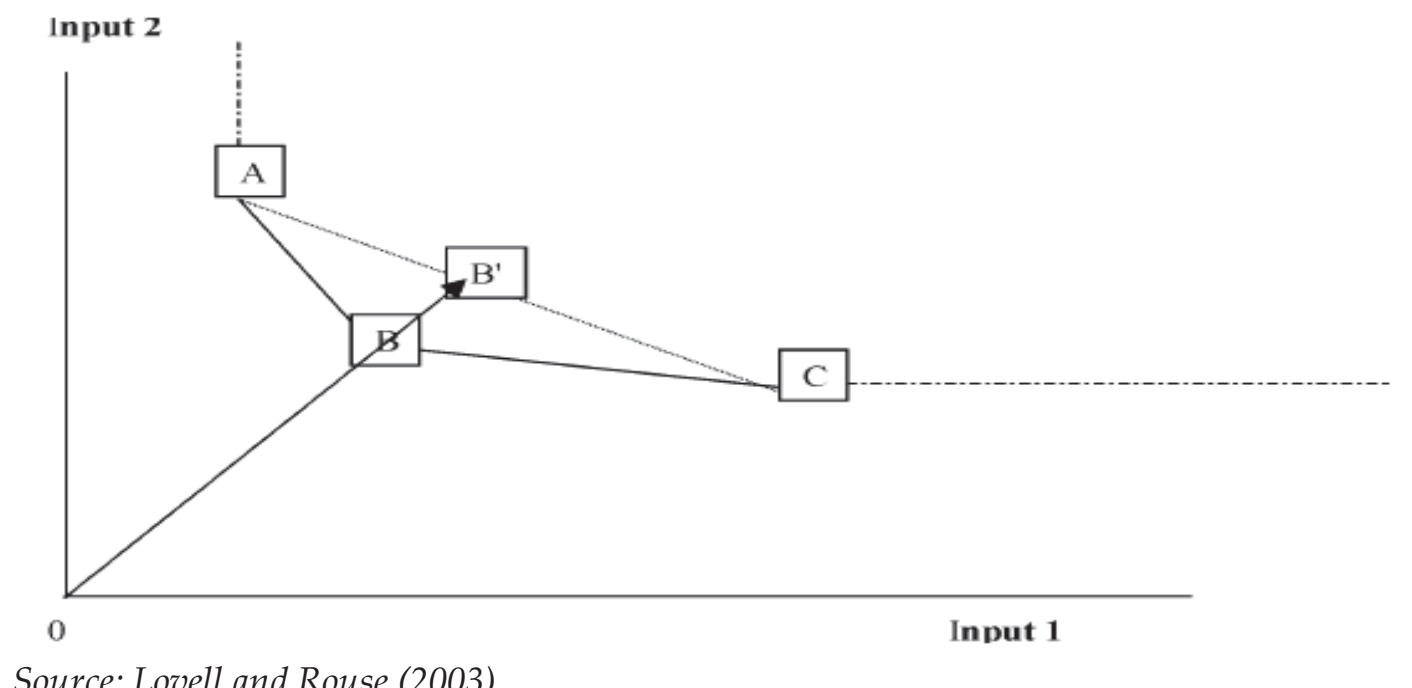

Source: Lovell and Rouse (2003)

Figure 3: Evaluating super-efficiency of DMU B

\section{Data collection and selection of inputs and outputs}

In the present study data has been collected from the MIX market database. The MIX Market compiles the database of microfinance institutions globally. The study is a cross-sectional in nature and pertains to 49 NBFI-MFIs for the financial year 2015. For the fiscal year 2015, complete data for the required fields was available for 49 MFIs. This study has focused exclusively on measuring the social efficiency and has not looked at the financial efficiency of MFIs. However, to have an idea about the financial sustainability of MFIs, we have looked at the operational self-sufficiency (OSS) of MFIs. The OSS ratio greater than one implies that MFIs are financially sustainable. In our sample, three MFIs have a ratio less than one. These three MFIs are Agora, BSFL, and Shikhar. Thus, these MFIs are not financially sustainable in their operations. To measure the social efficiency of MFIs variables have been culled out from the literature (see Table 1). 
Three standard inputs used are total assets, operating cost, and number of loan officers.

To ascertain the measures of output, we have followed closely the core social objectives of MFI by choosing variables that show outreach of the services to the poor and marginalized. In the literature women borrowers have served as an indicator to measure breadth of outreach (Bassem, 2008). Besides, number of poor served is another output used in the study. In order to arrive at number of poor, a poverty index on the lines of Gutierrez-Nieto et al. (2009) is constructed. Table 1 explains the methodology of obtaining the number of poorest reached.
We have followed Cooper et al. (2007) to check the adequacy of the sample The rule of thumb says sample size is adequate if

$$
\mathrm{n}>\max \{\mathrm{m} \times \mathrm{s}, 3(\mathrm{~m}+\mathrm{s})\},
$$

Where $\mathrm{n}, \mathrm{m}$, and $\mathrm{s}$ represent number of DMUs, inputs and outputs respectively. In our study $m=3$, $s=2$ and $n=49$, thus, our sample is adequate to do our analysis.

We have used gross loan portfolio to determine the size of MFIs in our sample. The top ten MFIs arranged in descending order of their size is given in Figure 4. Thus, Janalakshmi is the largest MFI in the sample under analysis. Further percentage of poor reached as a ratio of total number of active borrowers of these ten largest MFIs is given in Figure 5.

Table 1: Description of inputs and outputs

\begin{tabular}{|l|l|l|}
\hline Variables & Explanation & Supporting Literature \\
\hline Inputs & $\begin{array}{l}\text { Total Assets, adjusted for Inflation and } \\
\text { standardized fovisioning for loan } \\
\text { impairment and write-offs }\end{array}$ & $\begin{array}{l}\text { Gutierrez-Nieto et al. (2009); } \\
\text { Hassan et al. (2012); Servin } \\
\text { et al. (2012). }\end{array}$ \\
\hline $\begin{array}{l}\text { Operating Cost } \\
(\$)\end{array}$ & $\begin{array}{l}\text { Expenses related to operations, including all } \\
\text { personnel expense, depreciation and } \\
\text { amortization, and administrative expense }\end{array}$ & $\begin{array}{l}\text { Gutierrez-Nieto et al. (2007); } \\
\text { Gutierrez-Nieto et al. (2009); } \\
\text { Haq et al. (2010); Annim } \\
\text { (2012); Hassan et al (2012); } \\
\text { Servin et al. (2012); Lebovics } \\
\text { et al. (2016) }\end{array}$ \\
\hline $\begin{array}{l}\text { Lumber } \\
\text { Loan officers }\end{array}$ & $\begin{array}{l}\text { Persons directly related to loan-related } \\
\text { activities and responsible for arranging and } \\
\text { monitoring client loans }\end{array}$ & $\begin{array}{l}\text { Gutierrez-Nieto et al. (2007, } \\
\text { 2009); Hassan et al. (2012). }\end{array}$ \\
\hline $\begin{array}{l}\text { Outputs } \\
\text { active womber }\end{array}$ & $\begin{array}{l}\text { Number of women borrowers with loans } \\
\text { outstanding adjusted for standardized write- } \\
\text { offs }\end{array}$ & $\begin{array}{l}\text { (2012), Gutierrez-Nieto et al. } \\
\text { (2009). }\end{array}$ \\
\hline
\end{tabular}




\begin{tabular}{|l|l|l|}
\hline $\begin{array}{l}\text { Number of } \\
\text { poor reached }\end{array}$ & $\begin{array}{l}\text { Calculated using the index for ith MFI as } \\
P_{\mathrm{i}}=\left[1-\frac{A L B_{\mathrm{i}}-\operatorname{Min}(A L B)}{\operatorname{Range}(A L B)}\right] \times \text { (Number of active } \\
\left.\text { borrowers }_{\mathrm{i}}\right)\end{array}$ & $\begin{array}{l}\text { Gutierrez-Nieto et al. (2009), } \\
\text { Lebovics et al. (2016) }\end{array}$ \\
\hline
\end{tabular}

Note: Definition of inputs and outputs is drawn from MIX market database

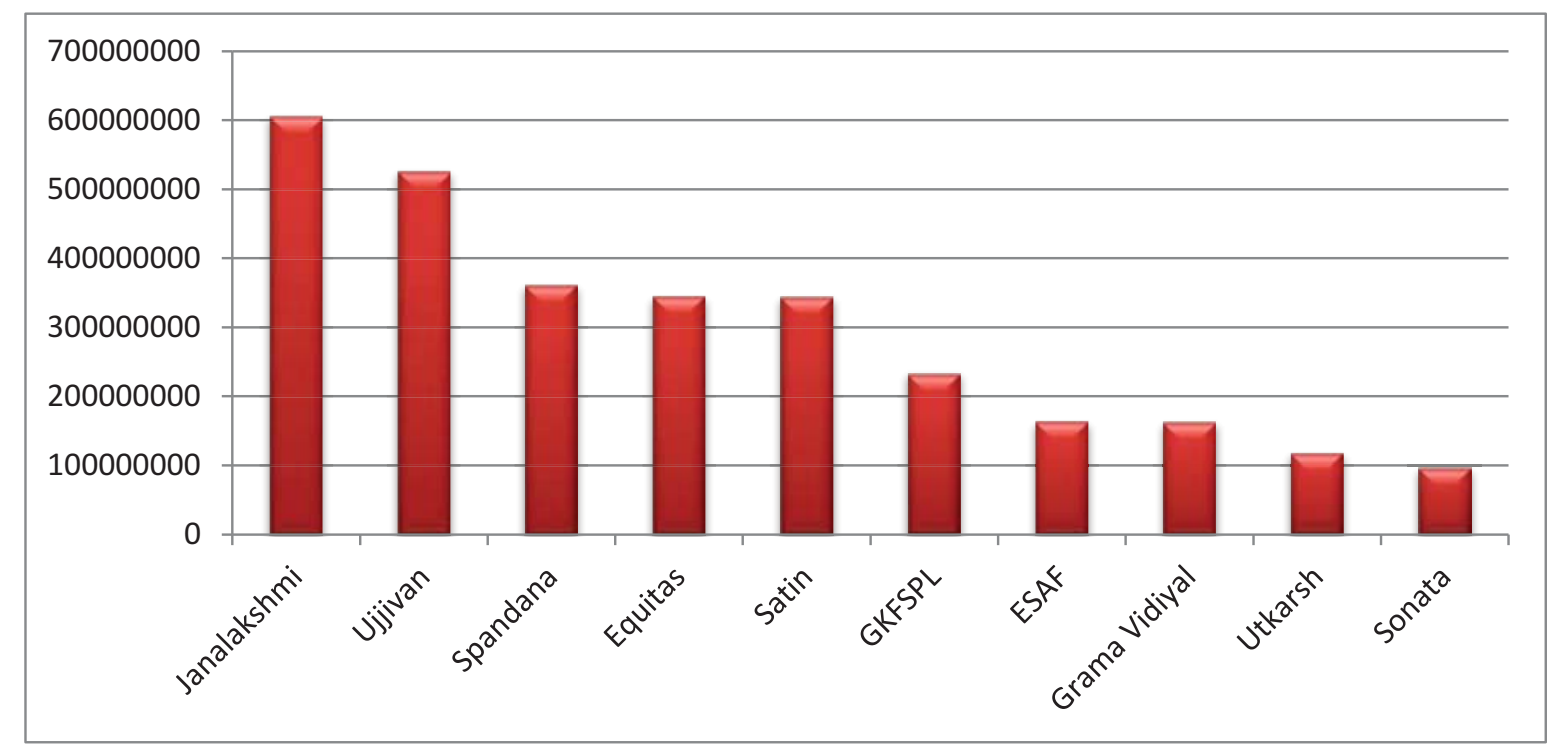

Source: Based on MIX market data for the fiscal year 2015

Figure 4: Top 10 MFIs according to the size of Gross Loan Portfolio (\$) in the sample

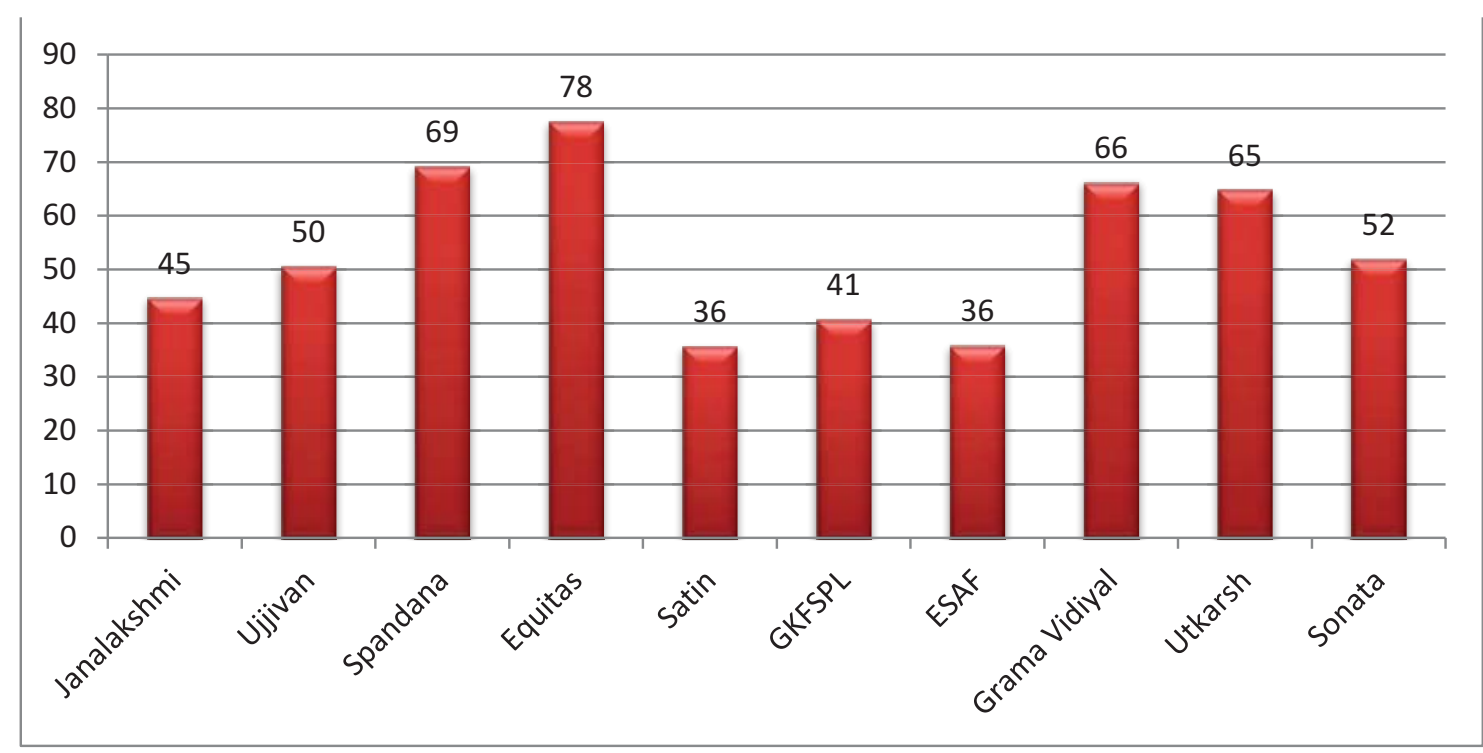

Source: Based on MIX market data for the fiscal year 2015 and index to reach the poorest

Figure 5: Percent of poorest reached as a ratio of number of active borrowers by 10 largest MFIs in the sample 


\section{INTERPRETATION OF RESULTS}

Results in Table 3 show the CRS-DEA efficiency scores. Efficiency score 1 implies that MFIs are efficient. Efficiency score less than 1 eventually points out that MFIs are relatively inefficient. Column 2 of Table 3 shows that only six of the 49 NBFI-MFIs are efficient and, thus, these MFIs form the efficiency frontier. Average social efficiency is found to be 0.66 and scores lie between 0.25 and 1 . Therefore, on average NBFI-MFIs in India, waste inputs to the extent of 34 percent. Column 3 shows the inefficiency of individual MFI. As column 2 shows equal scores i.e. perfect 1 has been assigned to the efficient MFIs, thus, to make a distinction between efficient MFIs super efficiency scores have been calculated in column 4 . In column 5 , ranking of MFIs has been done based on the super efficiency scores. BSFL has turned out as the most efficient MFI followed by Spandana, Smile, Equitas, Future, and Sarvodaya.

\section{Segregation of inefficient units}

In order to target inefficient MFIs that need the most attention, segregation of inefficient MFIs is done based on the quartile value. Table 2 gives descriptive statistics of social efficiency scores. Figure 6 makes use of quartiles values calculated in Table 2 as a cutoff point to segregate MFIs into different efficiency zones. Those MFIs who scored less than the first quartile have been labeled as 'most inefficient'. Further, MFIs whose efficiency score lies between first and second quartile have been categorized under 'below average' performer. Similarly, MFIs with a score between second and third quartile have been labeled as 'above average' performer and those with a score above the third quartile has been identified as 'marginally inefficient' MFIs (Figure 6). Thus, Chaitanya, Nirantara, and Janalakshmi are the bottom three performers on the social efficiency front. On the other hand, MFIs whose scores are greater than the third quartile are marginally behind the efficient category and can be brought to the efficient frontier with small changes in the utilization of resources. For instance, Asomi, ASA, and Adhikar are under the marginally inefficient category. MFIs in the 'most inefficient' category need to give special attention to their resource utilization. For the sake of brevity, only first four characters of the name of MFIs have been used in Figure 6.

Table 2: Descriptive statistics of CRS Social Efficiency scores

\begin{tabular}{|l|c|c|c|}
\hline No. of MFIs & 49 & Standard Deviation & 0.19 \\
\hline Mean & 0.66 & Quartile 1 & 0.54 \\
\hline Minimum & 0.25 & Quartile 2 & 0.63 \\
\hline Maximum & 1.00 & Quartile 3 & 0.76 \\
\hline
\end{tabular}

\section{Improving the efficiency of relative inefficient MFIs}

Further, to improve the efficiency and to make MFIs Pareto optimal input and output slacks have been calculated for each MFI (see Annexure 1). Slacks exist only for inefficient DMUs. The slack analysis contains the possibility of cutting back on inputs and increase in outputs to bring inefficient units on the efficient frontier (after radial adjustments). The results from this analysis, therefore, can be used directly to ascertain how various MFIs can improve their performance to provide financial services to the target group of poor and women. Here we have taken the bottom three performers to show how slack analysis can be useful to detect the presence of wastage of inputs and to suggest ways of increasing outputs without increasing the inputs.

For instance, DEA score based on CCR model shows 
the social efficiency score of Janalakshmi is 0.41 . Thus, to enhance efficiency, Janalakshmi must reduce all the inputs proportionally by 59 percent (radial adjustment). However, even after reducing the inputs proportionally, the presence of input slack on operating cost shows it further needs to reduce the operating cost by 8.6 percent. The presence of slack on the number of poor reached shows Janalakshmi should increase its reach to the poor by 70 percent. A similar explanation can be extended to other inefficient MFIs. Efficiency score for Chaitanya is 0.35 . After the proportional reduction of inputs by 65 percent, positive slack on operating cost suggests there is a need to reduce the operating cost by 10 percent (approx). Current operating cost of Chaitanya is $\$ 20,14,219$ (for data on inputs and outputs see http://mixmarket.org). Our analysis shows that, after making radial and non-radial adjustments, it can be brought down to $\$ 5,13,974$. Furthermore, Chaitanya needs to increase its reach to the poor. Currently, it is reaching 37,794 poor; to be efficient it should reach 50,070 poor. For Nirantara social efficiency score is 0.25 . Positive slacks on the assets and operating cost are to the tune of 5 and 14 percent respectively. Thus after accounting for radial and non-radial adjustments, it appears that even if it reduces assets from $\$ 19,74,016$ to $\$ 3,95,726$, it can maintain the current level of output. Similarly, operating cost needs to be reduced from the current level of $\$ 2,72,809$ to $\$ 29,283$. Social inefficiency of another MFI, Asomi, is 11 percent. Thus, Asomi requires reducing all the input radially by 11 percent. It needs to increase the reach to the female borrowers marginally by 0.78 percent. From the current reach of 44,912 female borrowers, with the suggested amount of inputs, it should reach 45,264 female borrowers.

\section{Identifying reference set for inefficient MFIs}

In the preceding section, slacks have been identified to improve the efficiency of MFIs. In this section, benchmark MFIs have been identified for the inefficient MFIs to improve efficiency. The parametric techniques such as Cobb-Douglas function compare the performance of inefficient DMU against the average performance of DMUs. One advantage of DEA as non-parametric technique over parametric techniques is that it compares the performance of inefficient DMU against the efficient DMU/DMUs that follow the similar production process. The DMUs against which performance of inefficient DMUs are compared are known as benchmark DMUs or peer DMUs. These units are also known as reference set (Cooper et al, 2006). Annexure 2 shows the identified benchmark MFIs for the inefficient DMUs. For instance, for ASA India, identified benchmarks MFIs are BSFL and Spandana. Similarly, Asomi can follow the production practices of BSFL, Sarvodaya Nano, and Spandana to improve its efficiency. The DMU followed by other inefficient DMUs as benchmark for the maximum number of times is known as a global leader. Thus, Spandana has turned out to be a global leader as it has been followed by other inefficient MFIs 37 times.

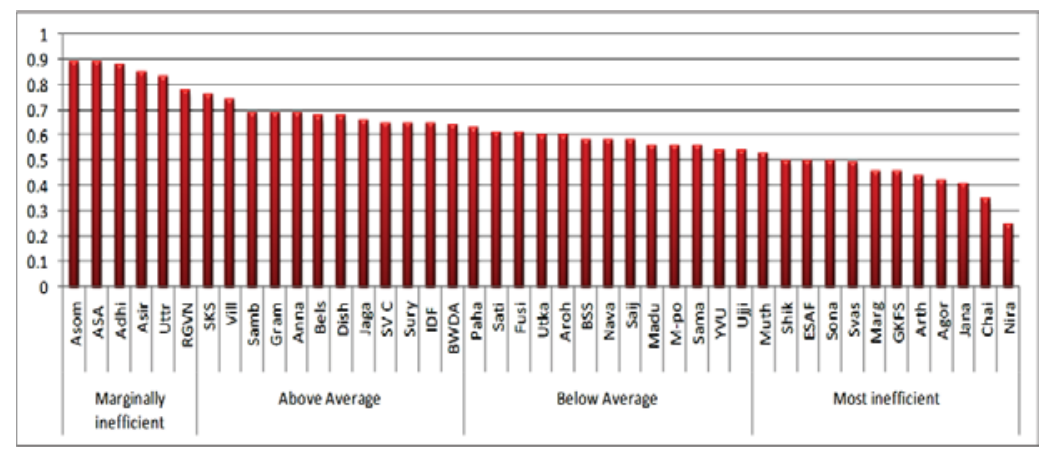

Source: Authors' analysis

Figure 6: Segregation of inefficient MFIs 
Table 3: Calculation of social efficiency and super efficiency of NBFI-MFIs in India

\begin{tabular}{|c|c|c|c|c|}
\hline MFIs & $\begin{array}{c}\text { CRS Social } \\
\text { Efficiency score }\end{array}$ & $\begin{array}{c}\text { Social } \\
\text { inefficiency } \\
(\%)^{\#}\end{array}$ & $\begin{array}{c}\text { Super } \\
\text { Efficiency (SE) }\end{array}$ & $\begin{array}{c}\text { Ranking based } \\
\text { on SE }\end{array}$ \\
\hline BSFL & 1 & 0 & 1.71 & 1 \\
\hline Spandana & 1 & 0 & 1.47 & 2 \\
\hline SMILE & 1 & 0 & 1.13 & 3 \\
\hline Equitas & 1 & 0 & 1.11 & 4 \\
\hline Future Financial & 1 & 0 & 1.09 & 5 \\
\hline Sarvodaya Nano & 1 & 0 & 1.01 & 6 \\
\hline Asomi & 0.89 & 11 & 0.89 & 7 \\
\hline ASA India & 0.89 & 11 & 0.89 & 8 \\
\hline Adhikar & 0.88 & 12 & 0.88 & 9 \\
\hline Asirvad & 0.85 & 15 & 0.85 & 10 \\
\hline $\begin{array}{l}\text { Uttrayan } \\
\text { Financial }\end{array}$ & 0.83 & 17 & 0.83 & 11 \\
\hline RGVN & 0.78 & 22 & 0.78 & 12 \\
\hline SKS & 0.76 & 24 & 0.76 & 13 \\
\hline Village Financial & 0.74 & 26 & 0.74 & 14 \\
\hline $\begin{array}{l}\text { Annapurna } \\
\text { Microfinance }\end{array}$ & 0.69 & 31 & 0.69 & 15 \\
\hline Grama Vidiyal & 0.69 & 31 & 0.69 & 16 \\
\hline Sambandh & 0.69 & 31 & 0.69 & 17 \\
\hline Disha Microfin & 0.68 & 32 & 0.68 & 18 \\
\hline Belstar & 0.68 & 32 & 0.68 & 19 \\
\hline Jagaran & 0.66 & 34 & 0.66 & 20 \\
\hline SV Creditline & 0.65 & 35 & 0.65 & 21 \\
\hline IDF Financial & 0.65 & 35 & 0.65 & 22 \\
\hline Suryoday & 0.65 & 35 & 0.65 & 23 \\
\hline BWDA & 0.64 & 36 & 0.64 & 24 \\
\hline Pahal & 0.63 & 37 & 0.63 & 25 \\
\hline Fusion & 0.61 & 39 & 0.61 & 26 \\
\hline Satin & 0.61 & 39 & 0.61 & 27 \\
\hline Arohan & 0.60 & 40 & 0.60 & 28 \\
\hline Utkarsh & 0.60 & 40 & 0.60 & 29 \\
\hline Saija & 0.58 & 42 & 0.58 & 30 \\
\hline Navachetana & 0.58 & 42 & 0.58 & 31 \\
\hline BSS & 0.58 & 42 & 0.58 & 32 \\
\hline Samasta & 0.56 & 44 & 0.56 & 33 \\
\hline M-power & 0.56 & 44 & 0.56 & 34 \\
\hline Madura & 0.56 & 44 & 0.56 & 35 \\
\hline
\end{tabular}




\begin{tabular}{|l|l|l|l|l|}
\hline YVU Financial & 0.54 & 46 & 0.54 & 36 \\
\hline Ujjivan & 0.54 & 46 & 0.54 & 37 \\
\hline Muthoot Fincorp & 0.53 & 47 & 0.53 & 38 \\
\hline Sonata & 0.50 & 50 & 0.50 & 39 \\
\hline ESAF & 0.50 & 50 & 0.50 & 40 \\
\hline Shikhar & 0.50 & 50 & 0.50 & 41 \\
\hline Svasti & 0.49 & 51 & 0.49 & 42 \\
\hline GKFSPL & 0.46 & 54 & 0.46 & 43 \\
\hline Margdarshak & 0.46 & 54 & 0.46 & 44 \\
\hline Arth & 0.44 & 56 & 0.44 & 45 \\
\hline Agora & 0.42 & 58 & 0.42 & 46 \\
\hline Janalakshmi & 0.41 & 59 & 0.41 & 47 \\
\hline Chaitanya & 0.35 & 65 & 0.35 & 48 \\
\hline Nirantara & 0.25 & 75 & 0.25 & 49 \\
\hline
\end{tabular}

\# Social inefficiency $=(1$ - social efficiency $){ }^{*} 100$

\section{CONCLUSION AND POLICY IMPLICATIONS}

In microfinance literature, analyzing the social efficiency of MFIs is gaining ground. However, not much has been researched upon the social efficiency of MFIs in India. Despite being hit hard by the Andhra Pradesh microfinance crisis in 2010, the sector has regained the confidence of the customers, the government of India and the Reserve Bank of India. Thus, this study has taken the opportunity to analyze how well MFIs in India are utilizing their resources to achieve their social objectives of reaching poor and women. The study also addresses the issue of wastage of resources which needs attention as plugging the wastage of resources will enable MFIs to reach more number of poor and women without increasing the level of inputs.

Our analysis shows that out of 49 NBFI-MFIs studied, six MFIs are on the efficiency frontier. These six relative efficient MFIs are ranked in descending order of their super efficiency scores as BSFL, Spandana, Smile, Equitas, Future, and Sarvodaya. Average social efficiency is found to be 0.66 and scores lie between 0.25 and 1 . Therefore, the results of input-oriented DEA model indicate that wastage of resources on an average can be reduced by 34 percent while maintaining the same level of outreach to women and poor. After the radial reduction of inputs, further to make MFIs Pareto optimal, slack analysis has been used. Thus, for individual MFIs input and output slacks have been identified to bring them on the efficiency frontier. To identify MFIs that require most attention segregation of MFIs is done using the quartile values. Thus, Janalakshmi, Chaitanya, and Nirantara require special attention, whereas MFIs like Asomi, ASA, Adhikar etc. needs marginal improvement to be on the efficient frontier. For instance, we have found that to enhance efficiency, Janalakshmi must reduce all the inputs proportionally by 59 percent (radial adjustment). However, even after reducing the inputs proportionally, the presence of input slack on operating cost shows it further needs to reduce the operating cost by 8.6 percent. The presence of slack on the number of poor reached shows Janalakshmi should increase its reach to the poor by 70 percent. Further, the reference set for inefficient MFIs have been identified to improve the efficiency of relative inefficient MFIs.

The practical implications of these findings are relevant for the policymakers, donors, and government agencies. It is in the interest of these agencies to know which MFIs are serving their social objective in a relatively better way and it guides them for releasing grants and donations. In India, loans given to MFIs by banks come under priority 
sector lending. Thus, efficiency of MFIs to discharge their social objectives further justify this policy of the government and become one of the criteria for designing the future policy actions for the disbursement of the loans to MFIs. In recent times when the RBI is granting payment bank and small finance bank licenses to MFIs to achieve the objective of financial inclusion, the results of this study will help to identify MFIs that may qualify for such licenses in the future. This study has policy implications for the microfinance institutions as well, as it indicates their relative performance on social efficiency front in comparison to other MFIs and provides them the scope for improving efficiency by calculating the input and output slacks. In the current scenario, it has increasingly being sought that MFIs should meet their double bottom line. Thus, being financially efficient in their operation is equally important for MFIs. In our sample, BSFL is the most efficient MFIs in reaching poor and women. However, operational self-sufficiency of BSFL is low and hence it is not financially sustainable. For sustaining the objective of serving the poor and women, MFIs should also focus on their financial sustainability.

The limitation of the study is that sample size is small and it is cross-sectional in nature. A longitudinal study covering a longer time horizon could provide a deeper insight into the efficiency analysis of MFIs in India on the social front. Incorporating the analysis of financial efficiency of MFIs can also add value to the study.

\section{REFERENCES}

1) Andersen, P. and Petersen, N.C., 1993. A procedure for ranking efficient units in data envelopment analysis. Management Science, 39(10), pp.1261-1264.

2) Annim, S.K., 2012. Microfinance efficiency: trade-offs and complementarities between the objectives of microfinance institutions and their performance perspectives. The European Journal of Development Research, 24(5), pp.788-807.
3) Avkiran, N.K., 2006. Productivity analysis in the service sector with data envelopment analysis. 3rd ed., the University of Queensland, Brisbane.

4) Azad, M.A.K., Masum, A.K.M., Munisamy, S. and Sharmin, D.F., 2016. Efficiency analysis of major microfinance institutions in Bangladesh: a Malmquist index approach. Quality \& Quantity, 50(4), pp.1525-1537.

5) Bassem, B.S., 2008. Efficiency of microfinance institutions in the Mediterranean: an application of DEA. Transition Studies Review, 15(2), pp.343-354.

6) Brand, M., 2000. More bang for the buck: Improving efficiency. MicroBanking Bulletin, 4, pp.13-18.

7) Charnes, A., Cooper, W.W. and Rhodes, E., 1978. Measuring the efficiency of decision making units. European Journal of Operational Research, 2(6), pp.429-444.

8) Conning, J. and Morduch, J., 2011. Microfinance and social investment.Annu. Rev. Financ. Econ., 3(1), pp.407-434.

9) Cooper, W.W., Seiford, L.M. and Tone, K., 2006. Introduction to data envelopment analysis and its uses: with DEA-solver software and references. Springer Science \& Business Media.

10) Demirguç-Kunt, A., Klapper, L.F., Singer, D. and Van Oudheusden, P., 2015. The global findex database 2014: Measuring financial inclusion around the world. Policy Research Working Paper 7255, World Bank, Washington.

11) Farrington, T., 2000. Efficiency in Microfinance Institutions, Micro Banking Bulletin 4 (Feb. 2010): 1823.

12) Gutierrez-Goiria, J., San-Jose, L. and Retolaza, J.L., 2017. Social Efficiency in Microfinance Institutions: Identifying How to Improve It. Journal of International Development, 29(2), pp.259-280.

13) Gutierrez-Nieto, B., Serrano-Cinca, C. and Molinero, C.M., 2007. Microfinance institutions and efficiency. Omega, 35(2), pp.131-142.

14) Gutierrez-Nieto, B., Serrano-Cinca, C. and Molinero, C.M., 2009. Social efficiency in microfinance institutions. Journal of the 
Operational Research Society, 60(1), pp.104-119.

15) Hassan, M.K. and Tufte, D.R., 2001. The $x-$ efficiency of a group-based lending institution: The case of the Grameen Bank. World Development, 29(6), pp.1071-1082.

16) Hassan, K.M., Sanchez, B. and Ngene, G., 2012. Scales and technical efficiencies in Middle East and North African (MENA) micro financial institutions. International Journal of Islamic and Middle Eastern Finance and Management, 5(2), pp.157-170.

17) Haq, M., Skully, M. and Pathan, S., 2010. Efficiency of microfinance institutions: A data envelopment analysis. Asia-Pacific Financial Markets, 17(1), pp.63-97.

18) Hermes, N., Lensink, R. and Meesters, A., 2011. Outreach and efficiency of microfinance institutions. World Development, 39(6), pp.938948.

19) Hulme, D. and Maitrot, M., 2014. Has microfinance lost its moral compass? BWPI Working Paper 205.

20) Huq, B.I.A., Azad, M.A.K., Masum, A.K.M., Wanke, P. and Rahman, M.A., 2017. Examining the Trade-off Between Social Outreach and Financial Efficiency: Evidence from Microfinance Institutions in South Asia. Global Business Review, 18(3), pp. 617-28.

21) Kaur, P. and Dey, S., 2013. Andhra Pradesh Microfinance Crisis and its Repercussions on Microfinancing Activities in India. Global Journal of Management and Business Studies, 3(7), pp.695-702.

22) Lamberte, M.B. and Desrochers, M., 2002. Efficiency and Expense Preference in the Philippines' Cooperative Rural Banks (No. 200212). PIDS Discussion Paper Series.

23) Lebovics, M., Hermes, N. and Hudon, M., 2016. Are financial and social efficiency mutually exclusive? A case study of Vietnamese microfinance institutions. Annals of Public and Cooperative Economics, 87(1), pp.55-77.

24) Lovell, C.A.K. and Rouse, A.P.B., 2003. Equivalent standard DEA models to provide super-efficiency scores. Journal of the
Operational Research Society, 54(1), pp.101-108.

25) Nair, T. S., \& Tankha, A., 2014. Inclusive Finance India Report 2014. Access Publication.

26) Nair, V. (2015, April 8). RBI eases lending norms for microfinance companies. Live Mint. Retrieved from http://www.livemint.com/Industry/LM4OfET ppTduXTLQD6BovL/RBI-eases-lending-normsfor-microfinance-companies.html

27) Nghiem, H., Coelli, T. and Rao, P., 2006. The efficiency of microfinance in Vietnam: Evidence from NGO schemes in the north and the central regions. International Journal of Environmental, Cultural, Economic and Social Sustainability, 2(5), pp.71-78.

28) Paxton, J., 2007. Technical Efficiency in a Semi Formal Financial Sector: The Case of Mexico. Oxford Bulletin of Economics and Statistics, 69(1), pp.57-74.

29) Rangarajan Committee, 2008. Report of the committee on financial inclusion.Government of India.

30) Schreiner, M., 2002. Aspects of outreach: A framework for discussion of the social benefits of microfinance. Journal of International Development, 14(5), pp.591-603.

31) Servin, R., Lensink, R. and Van den Berg, M., 2012. Ownership and technical efficiency of microfinance institutions: Empirical evidence from Latin America. Journal of Banking \& Finance, 36(7), pp.2136-2144.

32) The Bharat Microfinance Report 2015. Sa-Dhan: The Association of community Development finance Institutions publication.

33) The MIX Market database. www. mixmarket.org.

34) Wijesiri, M., Yaron, J. and Meoli, M., 2017. Assessing financial and outreach efficiency of Microfinance Institutions. Do age and size matter? Journal of Multinational Financial Management, 14, pp 63-76.

35) Woller, G. M., Dunford, C., \& Woodworth, W., 1999. Where to microfinance. International Journal of Economic Development, 1(1), 29-64. 
Annexure 1: Input and Output Slacks based on DEA analysis

\begin{tabular}{|c|c|c|c|c|c|}
\hline \multirow[b]{2}{*}{ DMU } & \multicolumn{3}{|c|}{ Input Slack } & \multicolumn{2}{|c|}{ Output Slack } \\
\hline & Assets & Operating Cost & Loan officers & $\begin{array}{l}\text { No. of } \\
\text { women } \\
\text { reached }\end{array}$ & $\begin{array}{c}\text { No. of poorest } \\
\text { reached }\end{array}$ \\
\hline ASA India & 0 & $\begin{array}{c}580526.17 \\
(28.91)^{*}\end{array}$ & 0 & 0 & $\begin{array}{c}1713.21 \\
(1.96)\end{array}$ \\
\hline Adhikar & 0 & $\begin{array}{c}286059.44 \\
(43.02)\end{array}$ & 0 & 0 & $\begin{array}{c}6516.61 \\
(26.96)\end{array}$ \\
\hline Agora & 0 & $\begin{array}{c}111989.49 \\
(23.36)\end{array}$ & 0 & 0 & 0 \\
\hline $\begin{array}{l}\text { Annapurna } \\
\text { Microfinance }\end{array}$ & $\begin{array}{c}5205503 \\
(6.76) \\
\end{array}$ & 0 & 0 & 0 & $\begin{array}{c}39135.41 \\
(17.88)\end{array}$ \\
\hline Arohan & $\begin{array}{c}5515615 \\
(6.69)\end{array}$ & 0 & 0 & 0 & $\begin{array}{c}29842.65 \\
(14.33)\end{array}$ \\
\hline Arth & 0 & $\begin{array}{c}66310.8 \\
(13.98)\end{array}$ & 0 & 0 & - \\
\hline Asirvad & $\begin{array}{c}6931261 \\
(11.8)\end{array}$ & 0 & 0 & 0 & $\begin{array}{c}28186.77 \\
(15.25)\end{array}$ \\
\hline Asomi & 0 & 0 & 0 & $\begin{array}{c}352.12 \\
(0.78) \\
\end{array}$ & 0 \\
\hline BSFL & 0 & 0 & 0 & 0 & 0 \\
\hline BSS & $\begin{array}{c}5370990 \\
(8.19)\end{array}$ & 0 & 0 & 0 & $\begin{array}{c}63149.14 \\
(98.68)\end{array}$ \\
\hline BWDA & 0 & 0 & 0 & $\begin{array}{l}3673.7 \\
(10.48)\end{array}$ & $0(0)$ \\
\hline Belstar & 0 & $\begin{array}{c}137402.35 \\
(4.44)\end{array}$ & 0 & 0 & $\begin{array}{c}17947.7 \\
(15.01) \\
\end{array}$ \\
\hline Chaitanya & 0 & $\begin{array}{c}198703.3 \\
(9.87)\end{array}$ & 0 & 0 & $\begin{array}{c}12276.34 \\
(32.48)\end{array}$ \\
\hline Disha Microfin & 0 & $\begin{array}{c}597152.02 \\
(17.63)\end{array}$ & 0 & 0 & $\begin{array}{c}27066.66 \\
(27.95)\end{array}$ \\
\hline ESAF & 0 & $\begin{array}{c}1020001.24 \\
(7.65)\end{array}$ & 0 & 0 & $\begin{array}{c}231993.84 \\
(114.22)\end{array}$ \\
\hline Equitas & 0 & 0 & 0 & 0 & 0 \\
\hline Fusion & 0 & $\begin{array}{c}332804.77 \\
(7.84)\end{array}$ & 0 & 0 & $\begin{array}{c}38576.07 \\
(30.91)\end{array}$ \\
\hline Future Financial & 0 & 0 & 0 & 0 & 0 \\
\hline GKFSPL & $\begin{array}{c}22916019 \\
(8.32)\end{array}$ & 0 & 0 & 0 & $\begin{array}{c}306258.19 \\
(88.28)\end{array}$ \\
\hline Grama Vidiyal & 0 & $\begin{array}{c}3321153.61 \\
(21)\end{array}$ & 0 & 0 & $\begin{array}{c}86681.35 \\
(15.14)\end{array}$ \\
\hline IDF Financial & 1367985 & 0 & 0 & 0 & 8009.25 \\
\hline
\end{tabular}




\begin{tabular}{|c|c|c|c|c|c|}
\hline & \multicolumn{3}{|c|}{ Input Slack } & \multicolumn{2}{|c|}{ Output Slack } \\
\hline & (11.05) & & & & $(25.85)$ \\
\hline Jagaran & 0 & 0 & 0 & $\begin{array}{c}3494.85 \\
(3.37)\end{array}$ & 0 \\
\hline Janalakshmi & 0 & $\begin{array}{c}6248724.76 \\
(8.66)\end{array}$ & 0 & 0 & $\begin{array}{c}736455.02 \\
(70.27)\end{array}$ \\
\hline M-power & 0 & $\begin{array}{c}596965.41 \\
(32.59)\end{array}$ & 0 & 0 & $\begin{array}{l}8273.1 \\
(28.91)\end{array}$ \\
\hline Madura & 0 & $\begin{array}{c}30942.56 \\
(0.72)\end{array}$ & 0 & 0 & $\begin{array}{c}25651.2 \\
(12.14) \\
\end{array}$ \\
\hline Margdarshak & 0 & $\begin{array}{l}157278 \\
(12.05)\end{array}$ & 0 & 0 & $\begin{array}{l}25043.26 \\
(158.01)\end{array}$ \\
\hline Muthoot Fincorp & $\begin{array}{c}446330.5 \\
(52.62)\end{array}$ & 0 & $\begin{array}{c}9 \\
(52.83)\end{array}$ & 0 & 0 \\
\hline Navachetana & $\begin{array}{c}473888.8 \\
(4.37)\end{array}$ & 0 & 0 & 0 & $\begin{array}{c}6103.16 \\
(23.82)\end{array}$ \\
\hline Nirantara & $\begin{array}{c}99936.85 \\
(5.06)\end{array}$ & $\begin{array}{c}39216.91 \\
(14.38)\end{array}$ & 0 & - & 0 \\
\hline Pahal & 0 & 0 & 0 & $\begin{array}{c}326.24 \\
(0.45)\end{array}$ & 0 \\
\hline RGVN & 0 & $\begin{array}{c}205492.59 \\
(6.01)\end{array}$ & 0 & 0 & $\begin{array}{c}7465.62 \\
(4.46)\end{array}$ \\
\hline SKS & 0 & $\begin{array}{c}10620474.24 \\
(15.21)\end{array}$ & 0 & 0 & $\begin{array}{c}345667.64 \\
(14.11)\end{array}$ \\
\hline SMILE & 0 & 0 & 0 & 0 & 0 \\
\hline SV Creditline & $\begin{array}{c}3591743 \\
(4.97) \\
\end{array}$ & 0 & 0 & 0 & $\begin{array}{c}48627.22 \\
(23.65) \\
\end{array}$ \\
\hline Saija & 0 & $\begin{array}{c}460637.99 \\
(17.77)\end{array}$ & 0 & 0 & $\begin{array}{c}3681.88 \\
(4.92)\end{array}$ \\
\hline Samasta & 0 & $\begin{array}{c}217051.27 \\
(18.24)\end{array}$ & 0 & 0 & $\begin{array}{c}5724.26 \\
(18.5)\end{array}$ \\
\hline Sambandh & $\begin{array}{c}691844.3 \\
(8) \\
\end{array}$ & 0 & 0 & 0 & $\begin{array}{c}3272.28 \\
(11.61) \\
\end{array}$ \\
\hline Sarvodaya Nano & 0 & 0 & 0 & 0 & 0 \\
\hline Satin & $\begin{array}{c}35995150 \\
(11.24) \\
\end{array}$ & 0 & 0 & 0 & $\begin{array}{c}478461.71 \\
(112.87)\end{array}$ \\
\hline Shikhar & 0 & $\begin{array}{c}31029.4 \\
(4.57)\end{array}$ & 0 & 0 & 0 \\
\hline Sonata & $\begin{array}{c}21918228 \\
(17.39) \\
\end{array}$ & 0 & 0 & 0 & $\begin{array}{c}98158.02 \\
(46.49) \\
\end{array}$ \\
\hline Spandana & 0 & 0 & 0 & 0 & 0 \\
\hline Suryoday & $\begin{array}{c}5608404 \\
(4.65)\end{array}$ & 0 & 0 & 0 & $\begin{array}{c}54711.44 \\
(17.29)\end{array}$ \\
\hline
\end{tabular}




\begin{tabular}{|l|c|c|c|c|c|}
\hline & \multicolumn{3}{|c|}{ Input Slack } & \multicolumn{2}{c|}{ Output Slack } \\
\hline Svasti & 0 & $\begin{array}{c}181123.78 \\
(16.98)\end{array}$ & 0 & 0 & $\begin{array}{c}6828.75 \\
(34.69)\end{array}$ \\
\hline Ujjivan & 0 & $\begin{array}{c}594990.04 \\
(1.22)\end{array}$ & 0 & 0 & $\begin{array}{c}558359.85 \\
(50.35)\end{array}$ \\
\hline Utkarsh & $\begin{array}{c}12894742 \\
(8.59)\end{array}$ & 0 & 0 & 0 & $\begin{array}{c}67981.53 \\
(17.25)\end{array}$ \\
\hline Uttrayan Financial & 0 & 0 & 40 & 0 & $\begin{array}{c}6988.02 \\
(15.8)\end{array}$ \\
\hline Village Financial & 0 & $\begin{array}{c}242991.91 \\
(10.72)\end{array}$ & 0 & 0 & 0 \\
\hline YVU Financial & 0 & $\begin{array}{c}26610.02 \\
(13.38)\end{array}$ & 0 & 0 & 0 \\
\hline
\end{tabular}

*Note: figure in parenthesis denotes percentage of slack to actual value of variables.

Annexure 2: Identifying reference set for socially inefficient NBFI-MFIs in India

\begin{tabular}{|c|l|l|}
\hline No. & DMU & Peer set/Benchmark DMUs \\
\hline 1 & ASA India & BSFL, Spandana \\
\hline 2 & Adhikar & BSFL, Spandana \\
\hline 3 & Agora & BSFL, SMILE, Spandana \\
\hline 4 & Annapurna Microfinance & Equitas, Spandana \\
\hline 5 & Arohan & Equitas, Spandana \\
\hline 6 & Arth & BSFL, Spandana \\
\hline 7 & Asirvad & Equitas, Future Financial \\
\hline 8 & Asomi & BSFL, Sarvodaya Nano, Spandana \\
\hline 9 & BSFL & BSFL, \\
\hline 10 & BSS & Equitas, Future Financial \\
\hline 11 & BWDA & BSFL, Sarvodaya Nano, Spandana \\
\hline 12 & Belstar & Equitas, Spandana \\
\hline 13 & Chaitanya & Equitas, Spandana \\
\hline 14 & Disha Microfin & Equitas, Spandana \\
\hline 15 & ESAF & Equitas, Spandana \\
\hline 16 & Equitas & Equitas \\
\hline 17 & Fusion & Equitas, Spandana \\
\hline 18 & Future Financial & Future Financial \\
\hline 19 & GKFSPL & Equitas, Spandana \\
\hline 20 & Grama Vidiyal & Equitas, Spandana \\
\hline 21 & IDF Financial & Equitas, Spandana \\
\hline 22 & Jagaran & Equitas, SMILE, Spandana \\
\hline & & \\
\hline
\end{tabular}




\begin{tabular}{|c|c|c|}
\hline 23 & Janalakshmi & Equitas, Spandana \\
\hline 24 & M-power & Equitas, Spandana \\
\hline 25 & Madura & Equitas, Spandana \\
\hline 26 & Margdarshak & Equitas, Spandana \\
\hline 27 & Muthoot Fincorp & Spandana \\
\hline 28 & Navachetana & Equitas, Spandana \\
\hline 29 & Nirantara & Equitas \\
\hline 30 & Pahal & Equitas, SMILE, Spandana \\
\hline 31 & RGVN & Equitas, Spandana \\
\hline 32 & SKS & Equitas, Future Financial \\
\hline 33 & SMILE & SMILE \\
\hline 34 & SV Creditline & Equitas, Spandana \\
\hline 35 & Saija & Equitas, Spandana \\
\hline 36 & Samasta & Equitas, Spandana \\
\hline 37 & Sambandh & Equitas, Spandana \\
\hline 38 & Sarvodaya Nano & Sarvodaya Nano \\
\hline 39 & Satin & Equitas, Spandana \\
\hline 40 & Shikhar & BSFL, SMILE, Spandana \\
\hline 41 & Sonata & Equitas, Spandana \\
\hline 42 & Spandana & Spandana \\
\hline 43 & Suryoday & Equitas, Future Financial \\
\hline 44 & Svasti & Equitas, Spandana \\
\hline 45 & Ujjivan & Equitas, Future Financial \\
\hline 46 & Utkarsh & Equitas, Spandana \\
\hline 47 & Uttrayan Financial & BSFL, Spandana \\
\hline 48 & Village Financial & BSFL, SMILE, Spandana \\
\hline 49 & YVU Financial & BSFL, SMILE, Spandana \\
\hline
\end{tabular}

